\title{
IMPROVING YIELD OF TRANSPLANTED AMAN AND BORO RICE THROUGH TEGRA PACKAGE OF CULTIVATION
}

\author{
M.A.Kader ${ }^{{ }^{*}}$, M.S.R. Mia ${ }^{1}$, M.A. Kafi ${ }^{1}$, M. S. Hossain ${ }^{2}$ and N. Islam ${ }^{1}$ \\ ${ }^{1}$ Department of Agronomy, BAU, Mymensingh \\ ${ }^{2}$ Department of Agronomy and Haor Agriculture, Sylhet Agricultural University, Sylhet \\ Corresponding author: abdul.kader@bau.edu.bd
}

Key words: TEGRA; mechanical transplanting; rice yield gap; preventive plant protection

\begin{abstract}
The study investigated the yield performance of transplant aman rice cv. BRRI dhan49 and boro rice cv. BRRI dhan29 under improved package of cultivation (TEGRA) as compared to farmers' practice. TEGRA is a rice farming practice which includes use of quality seeds and healthy seedlings, transplanting with rice transplanter, use of herbicide, use of balanced fertilization and micronutrients, and preventive plant protection measures. The study during transplant aman season included two treatments on rice cultivation method viz. TEGRA package and farmers' practice while in boro rice four treatments viz. TEGRA package, farmers' practice with high inputs, farmers' practice with medium inputs and farmers' practice with low inputs. The yield and plant characters of both transplant aman and boro rice were significantly influenced by the TEGRA package of cultivation as compared to farmers' practice. TEGRA package of cultivation as compared to farmers' practice increased the grain yield by $18.3 \%$ in transplant aman rice and by $80 \%$ in boro rice with less cost of production as compared to farmers' practice, which eventually resulted $23 \%$ increase in gross return and $400 \%$ in net return. As a result, the benefit cost ratio of TEGRA package was much higher (1.35 and 2.20 during transplant aman rice and boro rice, respectively) compared to that of farmers' practice (1.07 and 1.30).
\end{abstract}

\section{Introduction}

Rice is the most important staple food in Bangladesh covering more than $80 \%$ of the food grains consumed in the country. Currently, $11.47 \mathrm{~m}$ hectares of land is occupied with rice cultivation having an annual production of about 34.36 million tons with an average yield of about $3.0 \mathrm{t} \mathrm{ha}^{-1}$ (BRRI, 2015a). On an average, the yield of the most popular transplant aman rice varieties ranges from 5.0 to 6.5 tha $^{-1}$, (BRRI 2015b). However, the grain yield of 7.78 tha $^{-1}$ of the variety BRRI dhan49 was also reported at filed level (Kamruzzaman, 2014).

The lower average yield of rice in the country is mainly due to inefficient management practices used by the farmers such as use of poor quality seeds, less care of seedlings in the nursery bed, manual transplanting, use of imbalanced fertilization, i improper weed and pest management practices etc Recently, a package of rice cultivation, known as TEGRA, has been developed. The package is comprised of use of high quality rice seeds, raising of seedlings with special care in tray, use of tender seedlings for transplanting using mechanical transplanter, application of herbicides, balanced fertilization and preventive crop protection measures. The availability of labor became very scarce with high wages of labor, manual transplantingleading to reduced profits to farmers. It has been reported that transplanting takes about 250-300 man-hours/ha which is roughly 25 percent of the total labor requirement of the crop (Singh et al. 1985).. Mechanical transplanting has become popular in many countries due to its multidimensional advantages. The TEGRA package is 
Kader et al.

expected to give at least $20 \%$ more yield to the farmers as compared to their own practice. Therefore, the present study was conducted to evaluate the growth and yield performance of transplant aman rice cv. BRRI dhan49 and boro rice cv. BRRI dhan29 under TEGRA package of cultivation and compare with farmers practices.

\section{Materials and Methods}

The study was conducted at the Agronomy Field Laboratory, Bangladesh Agricultural University (BAU), Mymensingh during the transplant aman season (July to November) in 2014 and boro season (December to June) in 2014-15 to ascertain the yield performance of transplant aman rice cv. BRRI dhan49 and boro rice cv. BRRI dhan29 under TEGRA package of cultivation as compared to farmers' practices. The study during transplant aman season included two treatments on rice cultivation method viz. TEGRA package and farmers' practice, while during boro season the experiment composed of four treatments on rice cultivation methods viz. TEGRA package of cultivation, farmers' practice with high inputs, farmers' practice with medium inputs and farmers' practice with low inputs. The major features of the agronomic practices followed in TEGRA package and farmers' practices are given in Tables 1-3. To know about the farmers' practice for transplant aman and boro rice cultivation, a questionnaire was prepared and collected from 20 farmers selected randomly from the village Boira, Mymensingh Sadar, Mymensingh and their cultivation practices such as seed collection, seedling raising technique, age of seedlings during transplanting, fertilizing dose and crop protection measures were noted. The experiments were laid out in a Randomized Complete Block Design (RCBD) with five replications with the unit plot size $10 \mathrm{~m} \mathrm{X} 12 \mathrm{~m}$ to facilitate the use of rice transplanter.

Table 1. Major features of agronomic practices for transplant aman rice cv. BBRI dhan49 under TEGRA package and farmers' practice

\begin{tabular}{lccc}
\hline \multicolumn{1}{c}{ Cultivation practices } & TEGRA & Farmers' Practice \\
\hline Quality of seeds & $\begin{array}{c}\text { Foundation seed from Bangladesh } \\
\text { Agricultural Development } \\
\text { Corporation (BADC) }\end{array}$ & Farmers' own seed \\
Method of raising & Tray method & $\begin{array}{c}\text { Conventional method in } \\
\text { nursery }\end{array}$ \\
seedling & 18 & 27 \\
Age of seedling (days) & Transplanter & Manual \\
Method of transplanting & $30 \mathrm{~cm} \times 14 \mathrm{~cm}$ & $25 \mathrm{~cm} \times 15 \mathrm{~cm}$ \\
Spacing of transplanting & Advanced care as per the protocol & Care taken as and when \\
Crop protection & & necessary \\
Fertilizer dose kgha $^{-1}$ & 185 & 200 \\
Urea & 120 & 120 \\
TSP & 85 & 80 \\
MoP & 70 & 45 \\
Gypsum & & \\
\hline
\end{tabular}


Improving Yield of Transplanted Aman and Boro Rice Through Tegra Package of Cultivation

Table 2. Major features of agronomic practices for boro rice cv. BBRI dhan29 under TEGRA package and farmers' practice

\begin{tabular}{|c|c|c|c|c|}
\hline $\begin{array}{l}\text { Cultivation } \\
\text { practices }\end{array}$ & $\begin{array}{l}\text { TEGRA } \\
\text { package }\end{array}$ & $\begin{array}{c}\text { Farmers' } \\
\text { practice with } \\
\text { High inputs }\end{array}$ & $\begin{array}{c}\text { Farmers' } \\
\text { practice with } \\
\text { medium inputs }\end{array}$ & $\begin{array}{l}\text { Farmers' } \\
\text { practice with } \\
\text { low inputs }\end{array}$ \\
\hline Quality of seeds & $\begin{array}{l}\text { Foundation seed } \\
\text { from BADC }\end{array}$ & $\begin{array}{l}\text { Farmers' own } \\
\text { seed }\end{array}$ & $\begin{array}{c}\text { Farmers' own } \\
\text { seed }\end{array}$ & $\begin{array}{l}\text { Farmers' own } \\
\text { seed }\end{array}$ \\
\hline $\begin{array}{l}\text { Method of raising } \\
\text { seedling }\end{array}$ & Tray method & $\begin{array}{l}\text { Conventional } \\
\text { method }\end{array}$ & $\begin{array}{l}\text { Conventional } \\
\text { method }\end{array}$ & $\begin{array}{l}\text { Conventional } \\
\text { method }\end{array}$ \\
\hline $\begin{array}{l}\text { Age of seedling } \\
\text { (days) }\end{array}$ & 30 & 45 & 45 & 45 \\
\hline $\begin{array}{l}\text { Method of } \\
\text { transplanting }\end{array}$ & Transplanter & Manual & Manual & Manual \\
\hline $\begin{array}{l}\text { Spacing of } \\
\text { transplanting }\end{array}$ & $30 \mathrm{~cm} \times 14 \mathrm{~cm}$ & $25 \mathrm{~cm} \times 15 \mathrm{~cm}$ & $25 \mathrm{~cm} \times 15 \mathrm{~cm}$ & $25 \mathrm{~cm} \times 15 \mathrm{~cm}$ \\
\hline Crop protection & $\begin{array}{l}\text { Advance care as } \\
\text { per the protocol }\end{array}$ & $\begin{array}{l}\text { As and when } \\
\text { necessary }\end{array}$ & $\begin{array}{l}\text { As and when } \\
\text { necessary }\end{array}$ & $\begin{array}{l}\text { As and when } \\
\text { Necessary }\end{array}$ \\
\hline \multicolumn{5}{|l|}{$\begin{array}{l}\text { Fertilizer dose* } \\
\text { kgha }^{-1}\end{array}$} \\
\hline Urea & 296.4 & 393 & 280 & 167 \\
\hline TSP & 103.74 & 130 & 104 & 72 \\
\hline $\begin{array}{l}\text { MoP } \\
\text { (MoP) }\end{array}$ & 111.15 & 36 & 26 & 16 \\
\hline Gypsum & 59.28 & 112 & 82 & 56 \\
\hline
\end{tabular}

* Under TEGRA Package Grozin (Zn fertilizer) @7.5 kg ha ${ }^{-1}$, Boron @ $2.5 \mathrm{~kg} \mathrm{ha}^{-1}$, Megma (Mg fertilizer) @ $15 \mathrm{~kg} \mathrm{ha}^{-1}$ and Thiovit ( fungicide) $7.5 \mathrm{~kg} \mathrm{ha}^{-1}$ were applied.

Table 3. The protocol of plant protection measures taken in in transplant aman and boro rice under TEGRA package of cultivation

\begin{tabular}{|c|c|c|c|c|c|c|c|c|}
\hline $\begin{array}{c}\text { Riffit (pre- } \\
\text { emergence } \\
\text { herbicide) }+ \\
\text { Lesar } \\
\text { (systemic } \\
\text { herbicide) } \\
\text { (3-7 days of } \\
\text { land } \\
\text { preparation) }\end{array}$ & $\begin{array}{c}1^{\text {st }} \text { Urea } \\
\text { and } \\
\text { Thiovit } \\
\text { (fungicide) } \\
(10-15 \\
\text { DAT) }\end{array}$ & $\begin{array}{c}\text { Virtako } \\
\text { (insecticid } \\
\text { e) }(15-20 \\
\text { DAT) }\end{array}$ & $\begin{array}{l}2^{\text {nd }} \text { Urea } \\
\text { and Land } \\
\text { drying } \\
(25-30 \\
\text { DAT) }\end{array}$ & $\begin{array}{c}3^{\text {rd }} \text { Urea, } \\
\text { MoP and } \\
\text { Virtako } \\
\text { (insecticide } \\
\text { ) (35-40 } \\
\text { DAT) }\end{array}$ & $\begin{array}{c}\text { Amistertop } \\
\text { (fungicide) } \\
\text { (50-55 } \\
\text { DAT) }\end{array}$ & $\begin{array}{c}\text { Score } \\
\text { (fungicide } \\
\text { ) (55-60 } \\
\text { DAT) }\end{array}$ & $\begin{array}{c}\text { Plenum } \\
\text { (insecticid } \\
\text { e) }(65-70 \\
\text { DAT) }\end{array}$ & $\begin{array}{c}\text { Amistertop } \\
\text { (fungicide) } \\
\text { + Filia } \\
\text { (fungicide) } \\
\text { (70-75 } \\
\text { DAT), if } \\
\text { diseases } \\
\text { seen }\end{array}$ \\
\hline
\end{tabular}

For TEGRA package, the seedlings were grown in tray with growing media of soil, ash and compost mixture (Fig.1A) and seedlings were transplanted using mechanical transplanter with $30 \mathrm{~cm} \times 16 \mathrm{~cm}$ spacing (Fig. 1B). Growing of seedlings in the media is required for machine transplanting of the seedlings For farmers' practice, seeds were collected from the farmers and the seedlings were transplated manually with $25 \mathrm{~cm} \mathrm{X} 15 \mathrm{~cm}$ spacing followed by the farmers. . Intercultural operations like gap filling, irrigations etc. were done as and when necessary. At crop maturity data on yield contributing characters were collected. Then grain yield was converted at $14 \%$ moisture and straws sun dried properly and then weighed. Data collected on different parameters were statistically analyzed using software,(MSTAT) and mean comparisons were made by Duncan's Multiple Range Test (Gomez and Gomez, 1984).
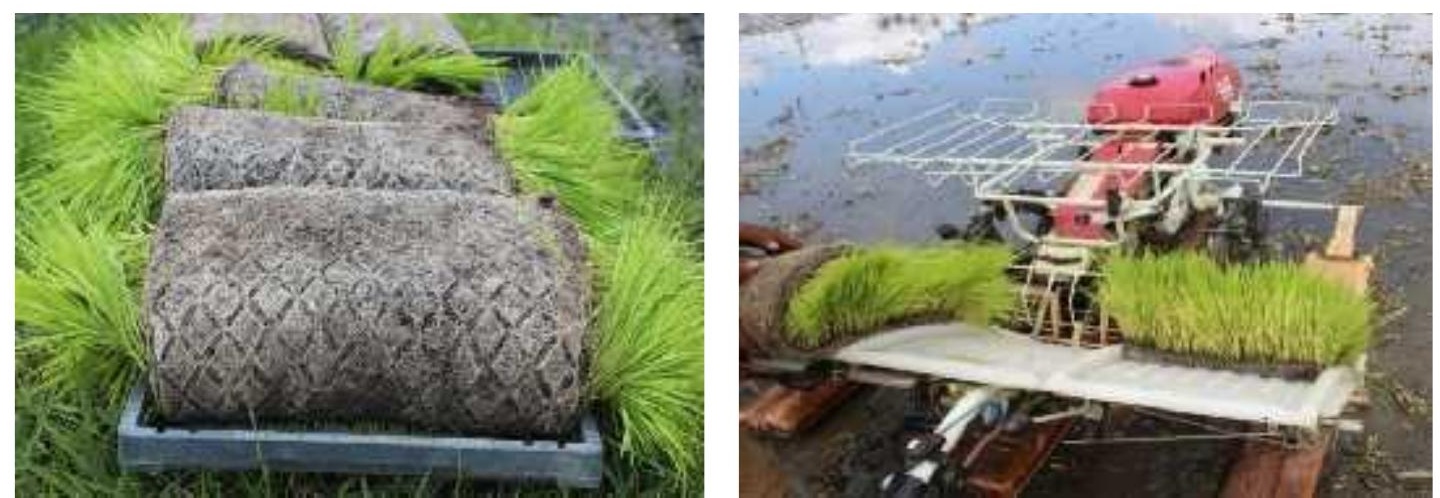
Kader et al.

\section{A}

Fig.1 Seedlings grown with special care in tray $(\mathrm{A})$ and transplanting with rice transplanter

(B)

\section{Results and Discussion}

\section{Yield and yield contributing characters of transplant aman rice cv. BRRI dhan49}

The effect of TEGRA package of cultivation was not significant in panicle length, grain numbers panicle ${ }^{-1}$, grain and straw yields (Table 4). The superior growth parameters of the crop under TEGRA package of cultivation was reflected in terms of number of total tillers $\mathrm{m}^{-}$ ${ }^{2}$, number of effective tillers $\mathrm{m}^{-2}$ and 1000-grain weight $(\mathrm{g})$. TEGRA package of cultivation produced significantly taller plant (103.8), higher number of total tillers hill ${ }^{-1}$ (429.35), effective tillers hill ${ }^{-1}$ (353.91) and 1000-grain weight $(19.70 \mathrm{~g})$ as compared to farmers' practice. Grain, straw and biological yields (grain yield + straw yield) of transplant aman rice cv. BRRI dhan49 under TEGRA package of cultivation were 5.88, 9.84 and 14.72, respectively as compared to farmers practice of $4.97,6.24$ and 11.21 , respectively. The results revealed that the grain yield of rice cv. BRRI dhan49 increased by $18.3 \%$ under TEGRA package of cultivation as compared to farmers' practice whereas straw yield increased by $57.69 \%$. The higher grain and straw yields obtained under TEGRA package of cultivation as compared to farmers' practice might be combined positive influence of all component technologies such as use of foundation seeds, better care of seedlings in the nursery, use of younger seedlings, better control of weeds and other pests, and use of balanced fertilization. Ali et al. (1992) also reported superior yield performance of rice with younger seedlings.

Profitability of transplant aman rice cv. BRRI dhan49 as compared to farmers' practice TEGRA package reduces the production cost of transplant aman rice by more than Tk. 3000 as compared to the farmers' practice (Table 5). This higher production cost under farmers' practice might be because of traditional way of transplanting and weeding requires more number of labors. Thus the results reveal that TEGRA package of cultivation was not only superior in terms of yield but also incurred less cost of production as compared to farmers' practices, besides increase in gross return $(23 \%)$ and net return $(400 \%)$ as compared to farmers' practice (Table 5). As a result, the benefit cost ratio of TEGRA package was higher (1.70) compared to that of farmers' practice.

Yield and yield contributing characters of boro rice cv. BRRI dhan29

TEGRA package of cultivation method had significant effect in respect of yield and all yield contributing characters of boro rice. The result showed that among the four cultivation methods used in TEGRA package where produced the highest number of total tillers $\mathrm{m}^{-2}$, number of effective tillers $\mathrm{m}^{-2}$ and 1000 -grain weight $(\mathrm{g})$ but farmers' practice with high 
Improving Yield of Transplanted Aman and Boro Rice Through Tegra Package of Cultivation

inputs did not give better results in yield components. The superior growth and yield parameters, adoption of TEGRA package produced the highest grain yield (10.89 $\left.\mathrm{t} \mathrm{ha}^{-1}\right)$ and straw yield $\left(12.43 \mathrm{t} \mathrm{ha}^{-1}\right)$. On the other hand, farmers' practice with high inputs produced the lowest grain yield $\left(6.17 \mathrm{t} \mathrm{ha}^{-1}\right)$. The results reveal that TEGRA package of cultivation increased grain yield of boro rice cv. BRRI dhan29 by $80 \%$ as compared to farmers' practices in general (average of farmers' practice with high, medium and low input). The increase of straw yield of the crop under TEGRA package of cultivation was $38.73 \%$ from that of farmers' practice with medium input. It is very clear from the results that TEGRA package of cultivation was much superior in producing grain and straw yield of boro rice cv. BBRI dhan29 as compared to any of the three farmers' practices.. Among the treatments on farmers practices, medium input was better than that of high $t$ and low input.

\section{Profitability of boro rice cultivation under TEGRA package of cultivation as compared to farmers' practices}

The production cost of boro rice cv. BRRI dhan29 under TEGRA package of cultivation was lower of Taka 9000 and 4000 as compared to farmers' practice with high and medium inputs, respectively. However, the production cost of the crop under TEGRA package of cultivation was a little higher than that of farmers' practice with low inputs. The traditional way of transplanting and weeding under farmers' practice required increased labor cost as compared to TEGRA package of cultivation. Eventually, TEGRA package of cultivation produced the highest gross and net return as compared to the other farmers' practices. The BCR of TEGRA package of cultivation was 2.20 which was only 1.18 under farmers' practice with high input. Similar results were also found by Singh et al. (2005) who stated that the mechanical transplanting was most cost-effective providing maximum benefit cost ratio.

\section{Conclusion}

From the results of the study it could be concluded that TEGRA package of rice cultivation is advantageous in terms of yield and cost of production of both transplant aman and boro rice under Bangladesh context. The technology might play a very vital role in increasing rice production in the country if it is adopted at farmers' level successfully at large scale and therefore requires more research in this area.

Table 4. Yield and yield contributing characters of transplant aman rice cv. BRRI dhan49 as influenced by TEGRA package of cultivation and farmers' practice

\begin{tabular}{l|c|c|c|c|c|c|c|c|c}
\hline Treatments & $\begin{array}{c}\text { No. of } \\
\text { total } \\
\text { tillers } \mathrm{m}^{-2}\end{array}$ & $\begin{array}{c}\text { No. of } \\
\text { effective } \\
\text { tillers } \mathrm{m}^{-2}\end{array}$ & $\begin{array}{c}\text { No. of } \\
\text { non- } \\
\text { effective } \\
\text { tillers } \mathrm{m}^{-2}\end{array}$ & $\begin{array}{c}\text { No. of grains } \\
\text { panicle }\end{array}$ & $\begin{array}{c}\text { No. of } \\
\text { sterile } \\
\text { spikelet } \\
\text { panicle }\end{array}$ & $\begin{array}{c}1000- \\
\text { grain } \\
\text { weight } \\
(\mathrm{g})\end{array}$ & $\begin{array}{c}\text { Grain yield } \\
\left.\text { ( hat }^{-1}\right)\end{array}$ & $\begin{array}{c}\text { Straw } \\
\text { yield } \\
\left(\mathrm{t} \mathrm{ha}^{-1}\right)\end{array}$ & $\begin{array}{c}\text { Biological } \\
\text { yield } \\
\left(\mathrm{t} \mathrm{ha}^{-1}\right)\end{array}$ \\
\hline TEGRA & $429.35 \mathrm{a}$ & $353.91 \mathrm{a}$ & $78.06 \mathrm{~b}$ & $128.5 \mathrm{~b}$ & $15.77 \mathrm{~b}$ & $19.70 \mathrm{a}$ & $5.88 \mathrm{a}$ & $9.84 \mathrm{a}$ & $15.72 \mathrm{a}$ \\
$\begin{array}{l}\text { Farmers' } \\
\text { practice }\end{array}$ & $396.02 \mathrm{~b}$ & $335.79 \mathrm{~b}$ & $90.61 \mathrm{a}$ & $134.7 \mathrm{a}$ & $20.90 \mathrm{a}$ & $17.60 \mathrm{~b}$ & $4.97 \mathrm{~b}$ & $6.24 \mathrm{~b}$ & $11.21 \mathrm{~b}$ \\
\hline $\mathrm{LSD}_{(0.05)}$ & 13.13 & 8.10 & 5.20 & 4.42 & 2.38 & 1.19 & 0.52 & 0.51 & 1.59 \\
$\mathrm{CV}(\%)$ & 1.81 & 1.34 & 3.51 & 1.93 & 7.38 & 3.65 & 5.48 & 3.65 & 4.43 \\
\hline
\end{tabular}

Table 5. Cost of production of transplant aman rice cv. BRRI dhan49 under TEGRA package of cultivation and farmers' practice

\begin{tabular}{c|c|c|c|c}
\hline Treatment & $\begin{array}{c}\text { Total cost } \\
\left(\text { Tk ha }^{-1}\right)\end{array}$ & $\begin{array}{c}\text { Gross Return } \\
\left(\text { Tk ha }^{-1}\right)\end{array}$ & $\begin{array}{c}\text { Net Return } \\
\left(\text { Tk ha }^{-1}\right)\end{array}$ & $\begin{array}{c}\text { Benefit Cost } \\
\text { Ratio (BCR) }\end{array}$ \\
\hline
\end{tabular}


Kader et al.

\begin{tabular}{ccccc}
\hline TEGRA & 121354.75 & 163680 & 43325.25 & 1.35 \\
$\begin{array}{c}\text { package } \\
\text { Farmer' } \\
\text { practice }\end{array}$ & 124645.50 & 133030 & 8384.50 & 1.07 \\
\hline
\end{tabular}

Table 6. Yield and yield contributing characters of boro rice cv. BRRI dhan29 as influenced by TEGRA package of cultivation and farmers' practices

\begin{tabular}{|c|c|c|c|c|c|c|c|c|c|c|}
\hline Treatment & $\begin{array}{c}\text { No. of } \\
\text { total } \\
\text { tillers } \mathrm{m}^{-2}\end{array}$ & $\begin{array}{c}\text { No. of } \\
\text { effective } \\
\text { tillers } \mathrm{m}^{-2}\end{array}$ & $\begin{array}{c}\text { No. of } \\
\text { non- } \\
\text { effective } \\
\text { tillers } \mathrm{m}^{-2}\end{array}$ & $\begin{array}{l}\text { Panicle } \\
\text { length } \\
(\mathrm{cm})\end{array}$ & $\begin{array}{c}\text { Number } \\
\text { of } \\
\text { grains } \\
\text { Panicle }^{-1}\end{array}$ & $\begin{array}{l}\text { Number } \\
\text { of } \\
\text { sterile } \\
\text { sikelets } \\
\text { Panicle }^{-1}\end{array}$ & $\begin{array}{l}1000- \\
\text { grain } \\
\text { weight } \\
\text { (g) }\end{array}$ & $\begin{array}{l}\text { Grain } \\
\text { yield } \\
\left.\text { (tha }^{-1}\right)\end{array}$ & $\begin{array}{l}\text { Straw } \\
\text { yield } \\
\left(\text { tha }^{-1}\right)\end{array}$ & $\begin{array}{l}\text { Biological } \\
\text { yield } \\
\left(\mathrm{t} \mathrm{ha}^{-1}\right)\end{array}$ \\
\hline $\begin{array}{l}\text { TEGRA } \\
\text { package }\end{array}$ & $664.02 \mathrm{a}$ & $639.50 \mathrm{a}$ & $24.51 \mathrm{~d}$ & $22.97 a$ & $137.9 a$ & $18.03 a$ & $22.24 \mathrm{a}$ & $10.89 a$ & $12.435 a$ & $23.32 a$ \\
\hline $\begin{array}{l}\text { practice } \\
\text { (high input) } \\
\text { Farmers' }\end{array}$ & $558.53 \mathrm{~b}$ & $492.61 \mathrm{~b}$ & $65.39 \mathrm{a}$ & $21.05 c$ & $106.6 \mathrm{~b}$ & $23.56 \mathrm{~b}$ & $21.09 b$ & $6.17 \mathrm{c}$ & 7.927c & $14.09 \mathrm{c}$ \\
\hline $\begin{array}{l}\text { practice } \\
\text { (medium } \\
\text { input) }\end{array}$ & $549.83 \mathrm{~b}$ & $504.19 b$ & $45.25 \mathrm{c}$ & $21.71 a$ & $121.9 \mathrm{~b}$ & $20.23 a$ & $20.51 b$ & $6.88 b$ & $8.960 \mathrm{c}$ & $15.84 b$ \\
\hline $\begin{array}{l}\text { Farmers' } \\
\text { practice } \\
\text { (low input) }\end{array}$ & $541.52 b$ & $499.44 \mathrm{~b}$ & $39.08 \mathrm{~b}$ & 20.91 & $117.3 \mathrm{c}$ & $18.93 c$ & $20.76 \mathrm{~b}$ & $6.39 b c$ & $8.125 b$ & $14.51 \mathrm{c}$ \\
\hline $\mathrm{LSD}_{(0.05)}$ & 36.85 & 36.65 & 6.78 & 0.501 & 5.13 & 1.33 & 1.18 & 1.09 & 0.257 & 1.25 \\
\hline CV (\%) & 4.04 & 4.34 & 9.79 & 1.49 & 3.02 & 4.79 & 3.54 & 6.96 & 2.56 & 5.06 \\
\hline
\end{tabular}

Table 7. Cost of production of boro rice cv. BBRI dhan29 under TEGRA package of cultivation and farmers' practices

\begin{tabular}{|c|c|c|c|c|}
\hline Treatments & $\begin{array}{l}\text { Total cost } \\
\left(\text { Tkha }^{-1}\right)\end{array}$ & $\begin{array}{l}\text { Gross } \\
\text { return } \\
\left(\mathrm{Tk} \mathrm{ha}^{-1}\right)\end{array}$ & $\begin{array}{l}\text { Net return } \\
\left(\mathrm{Tk} \mathrm{ha}^{-1}\right)\end{array}$ & $\begin{array}{l}\text { Benefit Cost } \\
\text { Ratio (BCR) }\end{array}$ \\
\hline TEGRA method & 124198.5 & 275340 & 151141.5 & 2.20 \\
\hline Farmers'practice (high input) & 133939.14 & 157764 & 23824.86 & 1.18 \\
\hline Farmers' Practice (medium input) & 128283.63 & 176160 & 45635.75 & 1.37 \\
\hline Farmers' practice (low input) & 121126.49 & 163220 & 42093.51 & 1.34 \\
\hline
\end{tabular}

\section{Reference}

Ali, M. Y., M. M. Rahman and M. M. Rahman. 1992. Effect of seedling age and transplanting time on late planted aman rice. Bangladesh J. Train. Develop. 5(2):75-89.

BRRI, 2015a. Rice Database: Rice Area, Production and Yield in Bangladesh. http://www.brri.gov.bd/site/page/f6e878c8-ceac-402d-9bed-6fb29a787428/RiceDatabase 29 December 2015.

BRRI, 2015b. Modern Rice Cultivation (in Bnagla) $18^{\text {th }}$ Edition. Bangladesh Rice Research Institute, Gazipur 1701. pp. 7-10.

Gomez, K. A. and A. A. Gomez. 1984. Statistical Procedure for Agricultural Research. $2^{\text {nd }}$. Ed. John Wiley and Sons, New York. pp. 97-111.

Kamruzzaman, M. 2014. Effects of Invinsa on the yield of transplant Aman rice cv. BRRI dhan49 under different dates of transplanting. M S Thesis. Department of Agronomy, Bangladesh Agricultural University, Mymensingh. p.40. 
Improving Yield of Transplanted Aman and Boro Rice Through Tegra Package of Cultivation

Singh, G., T. R. Sharma and C. W. Bockhop. 1985, Field performance evaluation of a manual rice transplanter. J. Agric. Engg. Res. 32: 259-268.

Singh, K. K., A. S. Jat, and S. K. Sharma. 2005. Improving productivity and profitability of rice (Oryza sativa)-wheat (Triticum aestivum) cropping system through tillage and planting management. The Indian J. Agril. Sci. 75(7): 396-399. 